\title{
Mídia, Educação e os jornais de amanhã
}

\section{Media, Education and tomorrow's newspapers}

\section{Alexandre FARBIARZ; Emmanoel Martins FERREIRA; Wagner da Silveira BEZERRA}

A terceira e última edição de 2015 da revista Mídia e Cotidiano consolida o fim de uma etapa de mudanças que acompanham o investimento permanente do Programa em fazer deste espaço um território firmemente articulado à realidade social do país. Isto se traduz, neste número, na reunião de artigos de várias tendências e espectros, no que denominamos Seção Livre. Nela, há discussões sobre a política brasileira recente, sobre o papel dos próprios jornalistas - seja sobre suas práticas, seja sobre a qualidade e credibilidade das notícias -, sobre as relações entre o discurso midiático e o cotidiano seja sob uma ótica ampla, seja uma mais específica, com enfoque nos desastres naturais. E, fechando a Seção, temos um artigo internacional que discute o papel que as rádios comunitárias digitais podem ter no empoderamento das comunidades.

Já em um contexto mais específico, alinhados pela perspectiva cada vez mais presente no PPGMC de uma relação profunda entre Comunicação e Educação, reunimos artigos sobre Mídia, Educação, Tecnologia e Comunicação na Seção Temática, com enfoque sobre experiências práticas. Por exemplo, o uso de programas radiofônicos e televisivos e também das mídias sociais em educação ou, ainda, o uso do cinema como espaço e ferramenta de transformação. Na mesma seção há artigos que discutem o papel do jornalista em projetos de comunicação e educação institucionais e sobre as relações entre mídia, política e educação.

Em sintonia à Seção Temática temos, neste número, uma entrevista com o professor Ismar Soares, atualmente Professor Titular e Coordenador da Licenciatura em Educomunicação da ECA/USP. O professor, um dos pioneiros dos estudos mídia e educação na América Latina, e criador do conceito educomunicação, fala sobre o campo da educação para as mídias e a contribuição educomunicativa à educação híbrida 


\section{míDiA

conectada, em especial sobre a ótica do empoderamento do aluno nos ambientes de ensino e aprendizagem.

Esta é, em síntese, a contribuição da Revista Mídia e Cotidiano ao cenário atual do país. E aqui vale - sob o risco de adentramos um lugar que às vezes parece um tanto longe demais do cotidiano acadêmico - compreender um pouco o que significa investir neste trabalho em um momento em que ler os jornais no Brasil tem sido um ato misto de coragem e de paixão. Coragem para suportar o descontentamento, o estupor, a fúria, pelas notícias sobre corrupção, política, economia, segurança, tudo embalado pela persistente e perversa desigualdade social histórica brasileira. Trata-se de um cenário de desnudamento de uma realidade conhecida mas não percebida ou, talvez, não assumida até hoje nesta forma tão avassaladora e intensa que só a coragem nos faz seguir adiante às próximas páginas do jornal. Coragem para suportar a dor da perda, do desespero, da sensação de impotência diante dos desastres não tão naturais, mas de proporções épicas, que assolam nosso país. A escassez de água e energia, o rompimento da barragem em Mariana, a seca, as enchentes, a fome, a morte. Coragem para suportar outras tantas páginas do jornal que nos revelam a dor mundo afora, o ódio, a intransigência, o extremismo.

Mas há, como dissemos, o outro lado, o lado da paixão de continuar lendo página após página dos jornais, dia após dia, acreditando que é possível, que podemos fazer algo de diferente, que podemos crer que o Brasil e o mundo vão investir, finalmente, em mudanças, que vão aprender e corrigir seus erros e que nós podemos fazer algo para que isso aconteça. Esta é a nossa paixão. É o que nos faz continuar pesquisando, escrevendo, ensinando e passando ao largo de clichês que, infelizmente já ouvimos, quanto à validade de se investir dinheiro e tempo públicos nestas investigações que talvez ainda soem para muitos como questões abstratas e intangíveis diante, por exemplo, de tantas urgências de transformações sociais, econômicas e políticas, pela perspectiva do senso comum.

Em outras palavras, publicar mais um número da Revista Mídia e Cotidiano é persistir neste caminho que escolhemos com a consciência de que nos pautamos pelo intuito de contribuir para que as pessoas possam ler as notícias nos jornais e não ficarem 


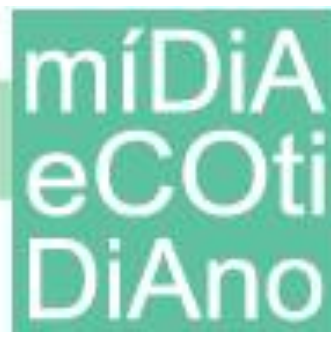

impassíveis, atônitas, impotentes. Para que se percebam cidadãos de um país, de um mundo; que possam entender o que ocorre ao seu redor e descubram como participar. Entender a mídia, para que possam atuar no seu cotidiano.

Mais do que isso - especialmente neste momento em que o PPG Mídia e Cotidiano, como tantos da nossa área, recebem mais um grupo de novos mestrandos -, precisamos todos entender nossos papéis transformadores desta sociedade em que vivemos, por mais injusta e até mesmo irracional que possa parecer. Precisamos acreditar que podemos transformar, que podemos participar e contribuir para a construção de uma sociedade melhor para nós e nossos filhos. Este é o nosso papel, este é o papel desta Revista.

E se isto pode parecer pouco - e é, mas fazemos parte de um território mais amplo e é nesta somatória de esforços que acreditamos - insistimos nesta empreitada, edição após edição. E, como dissemos inicialmente, esta convicção nos levou ampliar a periodicidade da Revista Mídia e Cotidiano de semestral para quadrimestral. A ela nos dedicamos, edição após edição, reunindo trabalhos de autores nacionais e internacionais que possam contribuir para que todos - autores, leitores, editores, alunos, professores, sociedade -, perscrutem novos caminhos, desvelem velhos mitos, espraiem os horizontes desta realidade cotidiana na qual estamos imersos e possam atuar em seus campos, midiáticos e educacionais, na mudança por algo melhor.

Que as notícias nos jornais de amanhã nos sejam mais palatáveis e esperançosas. A todos desejamos coragem e paixão no novo ano que já está aí, seguindo o fluxo do tempo com esta sóbria naturalidade que não impede que nós criemos estas marcas tão típicas das festas deste período: momentos de reflexão e recuperação dos sonhos e vontade de continuar. 